\title{
The synthesis of alkyl aryl nitriles from $N$-(1-arylalkylidene)- cyanomethyl amines: some mechanistic conclusions
}

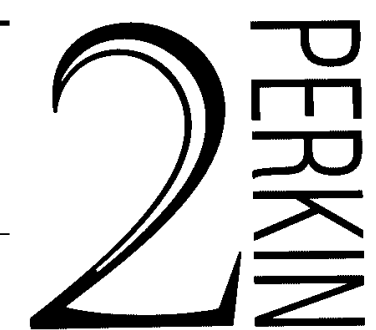

\author{
Alvise Perosa, Maurizio Selva * and Pietro Tundo \\ Dipartimento di Scienze Ambientali, Università Ca' Foscari, Dorsoduro 2137 - 30123 Venezia, \\ Italy.E-mail: selva@unive.it
}

Received (in Cambridge, UK) 9th July 1999, Accepted 26th August 1999

A mechanistic investigation of the rearrangement of $N$-(1-arylalkylidene)cyanomethylamines $\left[\mathbf{1}, \mathrm{ArC}\left(=\mathrm{NCH}_{2} \mathrm{CN}\right) \mathrm{R}\right.$;

$\mathrm{R}=$ alkyl, aryl] to alkyl aryl nitriles $[2, \operatorname{ArCH}(\mathrm{R}) \mathrm{CN}]$ in refluxing $\mathrm{DMF}$ in the presence of a base is reported.

Under these conditions, $p$-phenyl substituted $N$-(1-arylethylidene)cyanomethylamines $\left(\mathrm{Ar}=p\right.$ - $\mathrm{BrC}_{6} \mathrm{H}_{4}, p$ - $\mathrm{ClC}_{6} \mathrm{H}_{4}$, $p-\mathrm{CH}_{3} \mathrm{C}_{6} \mathrm{H}_{4}$ and $p-\mathrm{CH}_{3} \mathrm{OC}_{6} \mathrm{H}_{4} ; \mathrm{R}=\mathrm{CH}_{3}$ ) follow the Hammett linear free-energy relationship, with a large positive $\rho$ value (1.86), implying that electron-withdrawing substituents enhance the reaction rate by an initial deprotonation step. However, $C$-alkylated imines $\left[\mathrm{Ph}_{2} \mathrm{C}=\mathrm{NCH}\left(\mathrm{R}^{\prime}\right) \mathrm{CN} ; \mathrm{R}^{\prime}=\mathrm{Me}, n-\mathrm{Bu}\right]$ do not yield the corresponding nitriles

$\left[\mathrm{Ph}_{2} \mathrm{C}\left(\mathrm{R}^{\prime}\right) \mathrm{CN}\right]$, indicating the need for both methylene protons in order for the reaction to begin.

Different mechanistic pathways are then discussed. A base-catalysed imine double bond isomerisation, considered plausible, is excluded, since $\mathrm{N}$-alkylformimidoyl cyanides [ $\mathrm{ArCH}(\mathrm{N}=\mathrm{CHCN}) \mathrm{R}$ ] interconvert quantitatively to imines $\mathbf{1}$ prior to the formation of nitriles 2 . The photochemical activation of the reaction is also ruled out. The results of isotope labelling experiments, using ${ }^{13} \mathrm{C}$ - and ${ }^{15} \mathrm{~N}$-labelled $\mathrm{N}$-(1-phenylethylidene)cyanomethylamines $\left[\mathrm{PhC}\left(=\mathrm{NCH}_{2}-\right.\right.$ $\left.{ }^{13} \mathrm{CN}\right) \mathrm{CH}_{3}$ and $\left.\mathrm{PhC}\left(={ }^{15} \mathrm{NCH}_{2} \mathrm{CN}\right) \mathrm{CH}_{3}\right]$ are consistent with a mechanism based upon an intramolecular nucleophilic substitution reaction, since the cyano groups of the products $\mathbf{2}$ appear to come in preference from the methyleneiminic fragment $\left(=\mathrm{NCH}_{2}-\right)$ of the reagents.

The mechanism is proposed to proceed via an intermediate three-membered nitrogen heterocycle, generated by a nucleophilic intramolecular attack, which eliminates cyanide to afford the product nitrile.

\section{Introduction}

Alkyl aryl nitriles $[\mathrm{ArCH}(\mathrm{R}) \mathrm{CN}, 2]$ are widely used intermediates for the syntheses of a number of carboxylic acids or amines. ${ }^{1}$ A well-known example of their pharmaceutical relevance is the class of 2-arylpropionitriles $\left[\mathrm{ArCH}\left(\mathrm{CH}_{3}\right) \mathrm{CN}\right]$ which are intermediates for the preparation of hydratropic acids (2-arylpropionic acids), important non-steroidal analgesics such as Naproxen, Ibuprofen and Ketoprofen. ${ }^{2}$

We recently reported that nitriles 2 could be synthesised by a new two-step one-carbon homologation, starting from the corresponding ketone (ArCOR), via an intermediate $\mathrm{N}-(1-$ arylalkylidene)cyanomethylamine (1, Scheme 1$){ }^{3}$

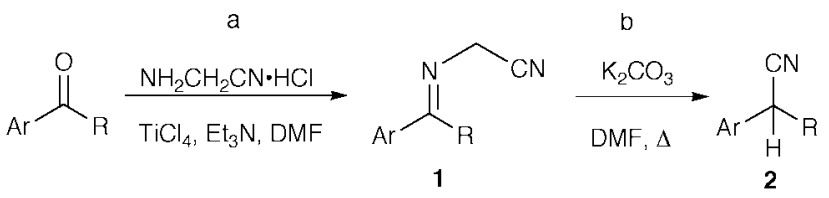

Scheme 1 A two-step homologation of alkyl aryl ketones to nitriles.

The alkyl aryl ketones were condensed with the hydrochloride salt of aminoacetonitrile to yield derivatives 1 [reaction (a)]. ${ }^{4}$ The resulting imines rearranged to nitriles $\mathbf{2}$ when heated in refluxing DMF, in the presence of a base $\left[\mathrm{K}_{2} \mathrm{CO}_{3}\right.$; reaction (b)], through a loss of HCN (see the Results and Discussion sections). The reaction (b) proceeded only at relatively high temperature $\left(T \geq 150^{\circ} \mathrm{C}\right)$ and although it turned out to be feasible both for alkyl aryl and diaryl ketones, the conditions appeared to be quite stringent. For example, both organic (i.e. $\mathrm{Et}_{3} \mathrm{~N}, \mathrm{Bu}_{3} \mathrm{~N}, \mathrm{DMAP}$ ) and inorganic (i.e. KF) bases, in the presence of different solvents such as polyethylene glycols, aromatic hydrocarbons, acetonitrile, THF, etc., were ineffective. Also, radical pathways were excluded: although photoactivation was reported for other imines and nitriles, ${ }^{5}$ compounds 1 yielded no reaction under photochemical activation (UV radiation: $500 \mathrm{~W}$ lamp). However, the influence of the specific reaction conditions was beyond the scope of the present study.

The novelty of such a transformation prompted us to undertake a mechanistic study of the reaction $\mathbf{1} \rightarrow \mathbf{2}$. This paper reports some conclusive results of the investigation.

\section{Results}

(i) Hammett free-energy relationship

Different $\quad p$-substituted $\quad N$-(1-arylethylidene)cyanomethyl amines $\left[\operatorname{aryl}=p-\mathrm{XC}_{6} \mathrm{H}_{4} ; \mathrm{X}=\mathrm{Br}(\mathbf{1 a}), \mathrm{Cl}(\mathbf{1 b}), \mathrm{H}\right.$ (1c), $\mathrm{CH}_{3} \mathrm{O}$ (1d), $\left.\mathrm{CH}_{3}(\mathbf{1 e})\right]$ were synthesised and reacted under the conditions of Scheme $1\left(\mathrm{~K}_{2} \mathrm{CO}_{3}\right.$ in refluxing DMF): ${ }^{3}$ solutions of 1a-e $(0.12 \mathrm{M})$ in $10 \mathrm{~mL}$ DMF were heated at reflux $\left(153^{\circ} \mathrm{C}\right)$, under nitrogen, in the presence of a 1.5 molar excess of $\mathrm{K}_{2} \mathrm{CO}_{3}$ [eqn. (1)].

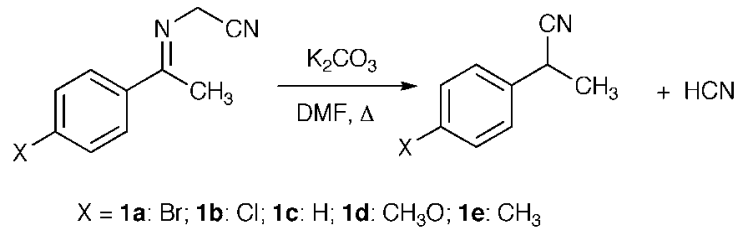

The reactions were followed by GLC and showed that the related concentration versus time plots fitted well the first-order rate law expression $\ln \left(C_{0} / C\right)=k t\left(C_{0}\right.$ and $C=$ substrate concentrations at $t=0$ and at a later time $t$, respectively).

As an example, by applying the integrated form of the firstorder kinetic equation to the disappearance curve of $\mathrm{N}$-(1phenylethylidene)cyanomethyl amine $\mathbf{1} \mathbf{c}^{6}{ }^{6}$ the resulting plot of $\ln \left(C_{0} / C\right)$ against time gave a straight line $(r>0.99)$, whose slope was the rate constant $k_{\text {obs }}$ of substrate disappearance (Fig. $1 ; k_{\mathrm{obs}}=8.1 \times 10^{-2} \mathrm{~min}^{-1}$ ). 
Table 1 The reaction of $\mathrm{XC}_{6} \mathrm{H}_{4} \mathrm{C}\left(=\mathrm{NCH}_{2} \mathrm{CN}\right) \mathrm{CH}_{3}$ in DMF solvent, in the presence of $\mathrm{K}_{2} \mathrm{CO}_{3}{ }^{a}$

\begin{tabular}{|c|c|c|c|c|c|}
\hline Entry & Substrate (X) & $k_{\mathrm{obs}}^{b} / 10^{-2} \mathrm{~min}^{-1}$ & $\sigma_{\mathrm{p}}^{c}$ & Product & Yield $(\%)$ by GC ${ }^{d}$ \\
\hline 1 & $\mathbf{1 a}(p-\mathrm{Br})$ & 25.0 & 0.26 & $p-\mathrm{BrC}_{6} \mathrm{H}_{4} \mathrm{CH}\left(\mathrm{CH}_{3}\right) \mathrm{CN} \mathbf{2 a}$ & 64 \\
\hline 2 & $\mathbf{1 b}(p-\mathrm{Cl})$ & 20.2 & 0.24 & $p-\mathrm{ClC}_{6} \mathrm{H}_{4} \mathrm{CH}\left(\mathrm{CH}_{3}\right) \mathrm{CN} \mathbf{2 b}$ & 47 \\
\hline 3 & $1 c(\mathrm{H})$ & 8.1 & 0 & $\mathrm{PhCH}\left(\mathrm{CH}_{3}\right) \mathrm{CN} 2 \mathrm{c}$ & 41 \\
\hline 4 & $\mathbf{1 d}\left(p-\mathrm{CH}_{3}\right)$ & 4.0 & -0.14 & $p-\mathrm{CH}_{3} \mathrm{C}_{6} \mathrm{H}_{4} \mathrm{CH}\left(\mathrm{CH}_{3}\right) \mathrm{CN} 2 \mathrm{~d}$ & 38 \\
\hline 5 & $1 \mathrm{e}\left(p-\mathrm{CH}_{3} \mathrm{O}\right)$ & 2.6 & -0.28 & $p-\mathrm{CH}_{3} \mathrm{OC}_{6} \mathrm{H}_{4} \mathrm{CH}\left(\mathrm{CH}_{3}\right) \mathrm{CN} 2 \mathrm{e}$ & 41 \\
\hline
\end{tabular}

${ }^{a}$ All reactions were carried out in refluxing DMF $\left(153^{\circ} \mathrm{C}\right)$ and using a 1.5 molar excess of the base. ${ }^{b}$ First-order rate constants for the disappearance of the substrate. ${ }^{c}$ Hammett $\sigma$ constants for $p$-phenyl substituents; from ref. 7 . $^{d}$ Yields are referred to the internal standards used: $n$-tetradecane (entries 1,3,4), $n$-hexadecane (entry 2) and $n$-dodecane (entry 5).

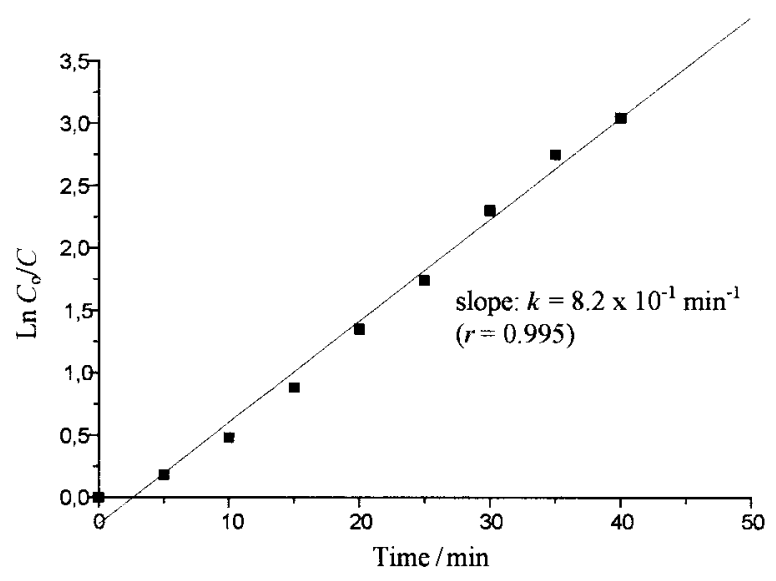

Fig. 1 Plot of $\ln C_{0} / C$ against time for imine 1c.

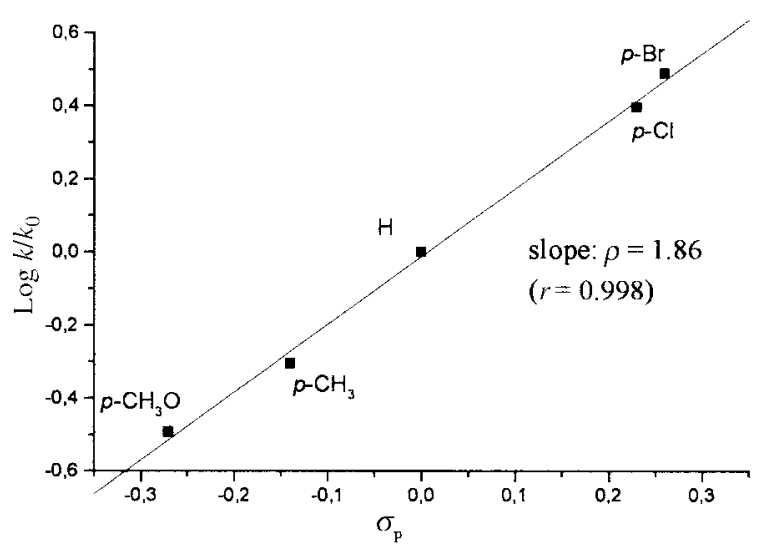

Fig. 2 Hammett plot for compounds 1a-1e.

Under the same conditions as for 1c, the first-order rate constants were evaluated for the disappearance of all imines 1a-e. Table 1 reports the results.

The reaction fitted the Hammett relationship equation, log $\left(k / k_{0}\right)=\sigma \rho$ [where $k$ and $k_{0}$ are the rate constants for the $p$-phenyl substituted $(\mathbf{1 a}-\mathbf{b}, \mathbf{d}-\mathbf{e})$ and the unsubstituted imines 1c, respectively, and $\sigma_{\mathrm{p}}$ constants are from ref. 7], giving a positive $\rho$ value of 1.86. Fig. 2 shows the results.

\section{(ii) Isomerisation of the iminic double bond under basic conditions}

To investigate how deprotonation and, possibly, isomerisation of ketimines could take place under the condition of Scheme 1 , $\mathrm{N}$-(1-phenylethylidene)benzylamine $\left[3 ; \mathrm{PhC}\left(=\mathrm{NCH}_{2} \mathrm{Ph}\right) \mathrm{CH}_{3}\right]$ was subjected to the same reaction conditions as for derivatives 1a-e, ${ }^{3}$ and a 40:60 mixture of isomers $\mathbf{3}$ and $\mathbf{3 a} \uparrow$ was obtained at equilibrium after $7.5 \mathrm{~h}$ [eqn. (2)], a result analogous to the reported base-catalysed interconversion between $\mathrm{Ph}_{2} \mathrm{C}=\mathrm{N}-$

$\dagger$ 3a was identified by comparison with an authentic sample prepared by condensing $\alpha$-methylbenzylamine with benzaldehyde.<smiles>C/C(=N\Cc1ccccc1)c1ccccc1</smiles>

$\mathrm{CH}_{2} \mathrm{Ph}$ and $\mathrm{Ph}_{2} \mathrm{CH}-\mathrm{N}=\mathrm{CHPh} .{ }^{7}$ No rearrangement to 2-phenylpropionitrile was observed.

On the other hand, the double bond isomers of imines $\mathbf{1}$, $\mathrm{N}$-alkylformimidoyl cyanides [RR' $\mathrm{CH}-\mathrm{N}=\mathrm{CHCN} ; 4]$ behaved differently. Compounds 4 [RR'CH-N=CHCN; 4c: $\mathrm{R}=\mathrm{Me}$, $\mathrm{R}^{\prime}=\mathrm{Ph}$; $\mathbf{f}: \mathrm{R}=\mathrm{R}^{\prime}=\mathrm{Ph} ; \mathbf{4 g}: \mathrm{R}=\mathrm{Et}, \mathrm{R}^{\prime}=\mathrm{Me}$ ] were synthesised by oxidising the appropriate amine $\left[\mathrm{RR}^{\prime} \mathrm{CHNHCH} \mathrm{H}_{2} \mathrm{CN}\right]$ with aqueous $\mathrm{NaOCl}$, in a one-pot $N$-chlorination-hydrodechlorination sequence.t The procedure afforded compound $\mathbf{4 g}$ as a pure product, while, in the cases of $\mathbf{4 f}$ and $\mathbf{4 c}$, a mixture of isomers was obtained (Scheme 2): $\mathbf{4} \mathbf{c}$ and $\mathrm{PhC}\left(=\mathrm{NCH}_{2} \mathrm{CN}\right) \mathrm{CH}_{3}$ 1c (44:1 ratio), and 4 f and $\mathrm{Ph}_{2} \mathrm{C}=\mathrm{NCH}_{2} \mathrm{CN}$ if (4:10 ratio).

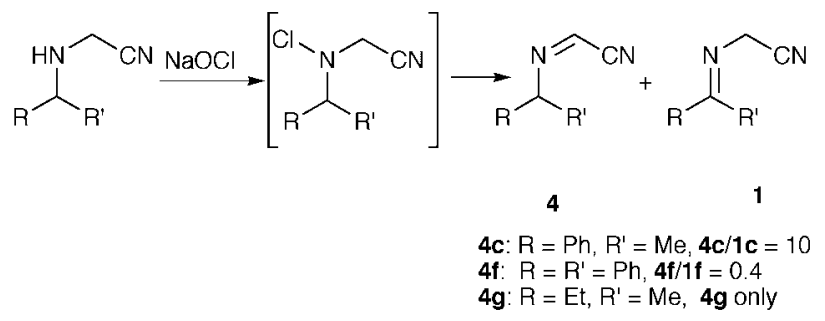

Scheme 2 Synthesis of $N$-alkylformimidoyl cyanides 4 .

Both imines $\mathbf{4} \mathbf{c}$ and $\mathbf{4 g}$ were reacted under the conditions of Scheme 1. Initially, they underwent a rapid and quantitative isomerisation to the corresponding imines $1\left[\mathrm{PhC}\left(=\mathrm{NCH}_{2} \mathrm{CN}\right)\right.$ $\mathrm{CH}_{3} \mathbf{1 c}$ and $\mathrm{CH}_{3} \mathrm{CH}_{2} \mathrm{C}\left(=\mathrm{NCH}_{2} \mathrm{CN}\right) \mathrm{CH}_{3} \mathbf{1 g}$, respectively]. While the further reaction of $\mathbf{1 g}$ afforded a mixture of high boiling compounds with no 2-methylbutanonitrile (the expected product according to Scheme 1), 1c underwent the previously observed rearrangement, after a $15 \mathrm{~min}$ induction time, affording 2c (Fig. 3 and Scheme 3).

The imine $1 \mathrm{~g}$ was also synthesised independently, ${ }^{4}$ and reacted under the same conditions to afford the same high boiling products observed in the case of $\mathbf{4 g}$. The 4:6 mixture of $\mathbf{4 f}$ and $\mathbf{1 f}$ was not reacted.

$\$$ The syntheses of compounds 4 is reported in the literature as a two step preparation: ${ }^{8}$ (i) the treatment of secondary amines with $\mathrm{Ca}(\mathrm{OCl})_{2}$, to isolate the corresponding $N$-chloro adduct, and (ii) the successive reaction of the chlorinated intermediate with a base to afford a single product, or mixture of isomers, depending on the substrate. In this work, the reported imines $\mathbf{4}$ were synthesized in one pot using a novel procedure, by treating cyanomethyleneamines directly with a commercial aqueous solution of $\mathrm{NaOCl}\left(10-13 \%\right.$ available chlorine). ${ }^{20}$ 


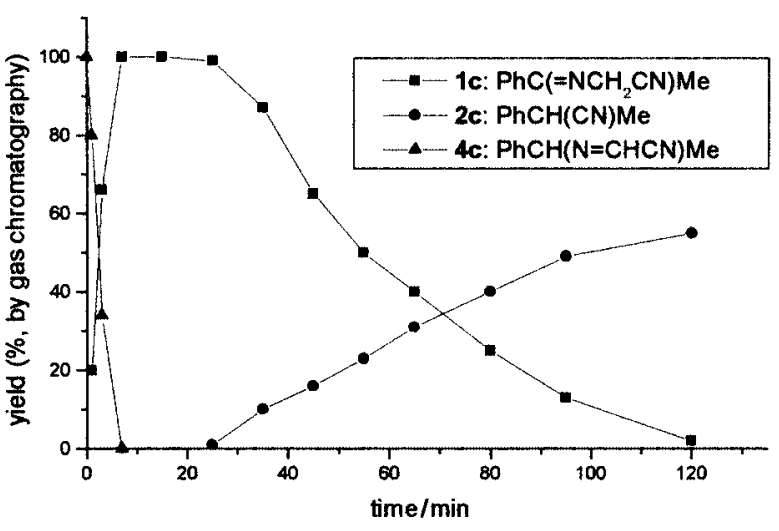

Fig. 3 Reaction of $\mathbf{4 c}$ under the rearrangement conditions of eqn. (1).

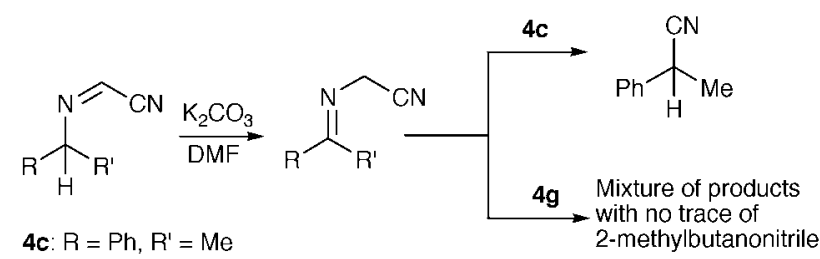

4g: $R=M e, R^{\prime}=E t$

Scheme 3 Isomerization of $N$-alkylformimidoyl cyanides.

\section{(iii) Reaction of 1 with $n$-BuLi}

Imine 1f was treated with $n$-BuLi in $\mathrm{THF}$ at $-90{ }^{\circ} \mathrm{C}$. The brown-red coloured solution was then heated at the reflux temperature of THF $\left(67^{\circ} \mathrm{C}\right)$ : no reaction was observed. However, when THF was distilled off and replaced with DMF, and the solution refluxed at $150^{\circ} \mathrm{C}$, the usual clean rearrangement to nitrile $\mathrm{Ph}_{2} \mathrm{CH}(\mathrm{CN}) 2 \mathbf{f}$ was observed. If, instead of replacing the solvent, the solution was quenched with either $n$-bromobutane or methyl iodide, it yielded the two alkylated imines $\mathrm{Ph}_{2} \mathrm{C}=$ $\mathrm{NCH}(n-\mathrm{Bu}) \mathrm{CN}$ 5a and $\mathrm{Ph}_{2} \mathrm{C}=\mathrm{NCH}\left(\mathrm{CH}_{3}\right) \mathrm{CN}$ 5b, respectively. Both $\mathbf{5 a}$ and $\mathbf{5 b}$ were subjected to the conditions of Scheme 1: only a mixture of products was detected, with no $\mathrm{Ph}_{2} \mathrm{C}(n-\mathrm{Bu})$ $\mathrm{CN}$ or $\mathrm{Ph}_{2} \mathrm{C}\left(\mathrm{CH}_{3}\right) \mathrm{CN}$ among them.

\section{(iv) Isotope labelling experiments}

A series of reactions was conducted using isotope labelled substrates. ${ }^{13} \mathrm{C}$ - and ${ }^{15} \mathrm{~N}$-labelled $\mathrm{N}$-(1-phenylethylidene)cyanomethylamines $\left[\mathrm{PhC}\left(=\mathrm{NCH}_{2}{ }^{13} \mathrm{CN}\right) \mathrm{CH}_{3}:{ }^{*} \mathbf{1 c}\right.$, and $\mathrm{PhC}\left(={ }^{15} \mathrm{NCH}_{2}-\right.$ $\mathrm{CN}) \mathrm{CH}_{3}$ : 1 $\mathbf{c}^{*}$, respectively] were synthesised independently, by condensing acetophenone with $\mathrm{NH}_{2} \mathrm{CH}_{2}{ }^{13} \mathrm{CN} \cdot \mathrm{H}_{2} \mathrm{SO}_{4}\left({ }^{13} \mathrm{C}\right.$, $99 \%$ ) and ${ }^{15} \mathrm{NH}_{2} \mathrm{CH}_{2} \mathrm{CN} \cdot \mathrm{H}_{2} \mathrm{SO}_{4}\left({ }^{15} \mathrm{~N}, 99 \%\right) .{ }^{4} \S$

The imines $* 1 \mathbf{c}$ and $1 \mathbf{c}^{*}$ were then reacted under the conditions of eqn. (1), and the outcome was monitored by GC/MS. In order to quantitatively evaluate the labelled isotopic enrichment of the resulting nitriles $\left[\mathrm{PhCH}\left(\mathrm{CH}_{3}\right)^{13} \mathrm{CN}\right.$ : $* 2 \mathrm{c}$ and $\mathrm{PhCH}\left(\mathrm{CH}_{3}\right) \mathrm{C}^{15} \mathrm{~N}$ : $2 \mathrm{c}^{*}$ ], two reference compounds were prepared: labelled $\left({ }^{13} \mathrm{C}, 99 \%\right)$ and unlabelled 2-phenylpropionitriles were synthesised by nucleophilic substitution with $\mathrm{Na}^{13} \mathrm{CN}$ $\left({ }^{13} \mathrm{C}, 99 \%\right)$ and $\mathrm{NaCN}$, on 1-chloro-1-phenylethane [PhCH$\left(\mathrm{CH}_{3}\right) \mathrm{Cl}$ ], according to reported conditions. ${ }^{9}$ The isotope distribution in the products of the rearrangement reactions conducted using the isotope enriched substrates is reported in Table 2.

The most significant mass peaks $\left[\mathbf{M}^{+}+1, \mathbf{M}^{+}, \mathbf{M}^{+}-1\right.$, $\left(\mathrm{M}^{+}+1\right)-\mathrm{CH}_{3}, \mathrm{M}^{+}-\mathrm{CH}_{3}$ and $\left.\left(\mathrm{M}^{+}-1\right)-\mathrm{CH}_{3}\right]$ are shown for both compounds $* \mathbf{2} \mathbf{c}$ and $\mathbf{2} \mathbf{c}^{*}$ (entries 1,2 ), and for the

$\S$ The structure of the imines * $\mathbf{1 c}$ and $\mathbf{1} \mathbf{c} *$ was confirmed by comparison of their mass spectra with that of the unlabelled compound 1c. The identification peaks of $* \mathbf{1} \mathbf{c}$ and $\mathbf{1} \mathbf{c}^{*}\left(\mathbf{M}^{+}=158, \mathbf{M}^{+}+1=159\right.$ and $\mathrm{M}^{+}-\mathrm{CH}_{3}=144$ ) were shifted by one mass unit with respect to $\mathbf{1 c}$, while their relative intensity was unchanged (see Experimental). 2-phenylproprionitrile standards (entries 3,4, respectively). We assumed the same response for $* \mathbf{2 c}$ and $\mathbf{2} \mathbf{c}^{*}$, which have equal molecular masses, with respect to the standards.

\section{(v) Titration of the cyanide released by the reaction $1 \rightarrow 2$}

Titration by $\mathrm{AgNO}_{3}$ of the aqueous extracts of the reaction of compound $\mathrm{Ph}_{2} \mathrm{C}=\mathrm{NCH}_{2} \mathrm{CN}$ 1f, under the conditions of Scheme 1 , yielded a molar amount of cyanide $(51 \%)$ corresponding to the isolated molar yield of diphenylacetonitrile $2 \mathbf{f}(48 \%)$.

\section{Discussion}

(i)-(iii) Hammett free-energy relationship, isomerisation of the iminic double bond, and reactions with $n$-BuLi

The investigation of the mechanism of the transformation $\mathbf{1} \rightarrow \mathbf{2}$ was first addressed by considering the effect of a series of parasubstituents on the aryl ring of $\mathbf{1}$. The trend of first-order rate constants $k_{\text {obs }}$ for the disappearance of imines 1a-e (Table 1) clearly shows that electron-withdrawing $p$-phenyl substituents enhance the reaction rate, while electron-donating ones decrease it with an overall variation (from $p$ - $\mathrm{Br}$ to $p-\mathrm{CH}_{3} \mathrm{O}$ ) by a factor of 10. Also, the positive $\rho$ value (1.86) obtained from the Hammett equation (Fig. 2) can be associated with a developing negative charge in a transition state more stabilised by electronwithdrawing substituents. ${ }^{10-12}$ If this is the case, the negative charge may develop initially by proton abstraction by the base on the methylene carbon; an hypothesis which seems further verified by both the equilibrium of eqn. (2) (whose establishment implies proton abstraction-migration from a methylene to an imine carbon), and the reaction of $\mathbf{1 f}$ with $n$-BuLi which yields an anion capable of affording diphenylacetonitrile upon reflux in a DMF solution. In both cases, the initial occurrence of a species such as $\mathrm{PhC}(=\mathrm{N} \bar{C} H R) \mathrm{R}^{\prime}\left(\mathbf{3}: \mathrm{R}=\mathrm{Ph}, \mathrm{R}^{\prime}=\mathrm{Me}\right.$; 1 : $\mathrm{R}=\mathrm{CN}, \mathrm{R}^{\prime}=\mathrm{Ph}$ ) seems more than reasonable.

Moreover, the proton shift of eqn. (2) suggests that the double bond isomers of imines $\mathbf{1}$, namely $N$-alkylformimidoyl cyanides 4 [formed in analogy to eqn. (2)], should also be expected to afford nitriles 2 .

However, the study of the reactivity of imines $\mathbf{4}$ proves that any mechanistic hypothesis based upon an initial isomerisation of 1 to 4 must be excluded. Under the conditions of Scheme 1, compounds $\mathbf{4 c}$ and $\mathbf{4 g}\left(\mathbf{c}: \mathrm{R}=\mathrm{Ph}, \mathrm{R}^{\prime}=\mathrm{Me} ; \mathbf{g}: \mathrm{R}=\mathrm{Et}, \mathrm{R}^{\prime}=\mathrm{Me}\right)$ first undergo complete isomerisation to the corresponding imines 1. Then, while 1c gives the usual clean rearrangement to 2-phenylpropionitrile, the dialkyl compound $\mathbf{1 g}$ furnishes only high boiling products with none of the expected nitrile (Scheme 3 and Fig. 3)

Further indirect evidence can be inferred by the preparation of the imines 4: while the dialkyl imine $\mathbf{4 g}$ and the alkylaryl imine $\mathbf{4 c}$ are obtained as single products, the attempt to synthesise the diaryl derivative $\mathbf{4 f}$ gives a mixture of $\mathbf{4 f} / \mathbf{1 f}$ in a $4: 10$ ratio. In the alkaline environment ( $\mathrm{NaOCl}$ aq.), 1 clearly represents the more stable highly conjugated structure.

However, the formation of nitriles 2 requires both protons at the methylene position: in fact, alkylated imines $\mathbf{5 a}$ and $\mathbf{5 b}$ $\left[\mathrm{Ph}_{2} \mathrm{C}(=\mathrm{NCHRCN}) ; \mathrm{R}=n\right.$-Bu, Me $]$ do not undergo the desired rearrangement, and yield a mixture of products.

(iv-v) Isotope labelling experiments, and titration of the cyanide released by the reaction $1 \rightarrow 2$

A different approach to the mechanistic investigation was aimed at establishing which part of the iminomethylenenitrile moiety $\left(=\mathrm{NCH}_{2}-\mathrm{CN}\right)$ of the reacting imines $\mathbf{1}$ is incorporated as the cyano functionality in nitriles $\mathbf{2}$.

As was noted earlier, $N$-(1-phenylethylidene)benzylamine 3 does not rearrange to 2-phenylpropionitrile, which means that the cyano fragment $\left(=\mathrm{NCH}_{2}-\mathbf{C N}\right)$ of the iminomethylene moiety of compounds $\mathbf{1 a}-\mathbf{e}$ is necessary for the reaction to 
Table 2 Isotopic enrichment of 2-phenylpropionitrile produced from different source compounds ${ }^{a}$

\begin{tabular}{|c|c|c|c|c|c|c|c|c|c|}
\hline \multirow[b]{2}{*}{ Entry } & \multirow[b]{2}{*}{ product } & \multicolumn{6}{|c|}{ Identifying mass peaks $(\%$, relative intensity) } & \multirow{2}{*}{$\begin{array}{l}\text { Isotopic } \\
\text { enrichment } \\
(\%)\end{array}$} & \multirow[b]{2}{*}{$\begin{array}{l}\text { Source } \\
\text { compound }\end{array}$} \\
\hline & & $\mathbf{M}^{+}+1$ & $\mathrm{M}^{+}$ & $\mathrm{M}^{+}-1$ & $\begin{array}{l}\left(\mathrm{M}^{+}+1\right)- \\
\mathrm{CH}_{3}\end{array}$ & $\mathrm{M}^{+}-\mathrm{CH}_{3}$ & $\begin{array}{l}\left(\mathrm{M}^{+}-1\right)- \\
\mathrm{CH}_{3}\end{array}$ & & \\
\hline 1 & $\mathrm{PhCH}\left(\mathrm{CH}_{3}\right)^{13} \mathrm{CN} * 2 \mathrm{c}$ & $133(1)$ & $132(17)$ & $131(27)$ & $118(5)$ & $117(65)$ & $116(100)$ & $\left({ }^{13} \mathrm{C}, 32\right)^{b}$ & $\mathrm{Ph}\left(=\mathrm{NCH}_{2}{ }^{13} \mathrm{CN}\right) \mathrm{CH}_{3}$ \\
\hline 2 & $\mathrm{PhCH}\left(\mathrm{CH}_{3}\right) \mathrm{C}^{15} \mathrm{~N} 2 \mathrm{c}^{*}$ & $133(3)$ & $132(37)$ & $131(34)$ & $118(6)$ & $117(100)$ & $116(83)$ & $\left({ }^{15} \mathrm{~N}, 57\right)^{b}$ & $\mathrm{Ph}\left(={ }^{15} \mathrm{NCH}_{2} \mathrm{CN}\right) \mathrm{CH}_{3}$ \\
\hline 3 & $\begin{array}{l}\mathrm{PhCH}\left(\mathrm{CH}_{3}\right)^{13} \mathrm{CN} \\
\text { (standard) }\end{array}$ & $133(3)$ & $132(37)$ & $131(4)$ & $118(8)$ & $117(100)$ & $116(-)$ & $\left({ }^{13} \mathrm{C}, 99\right)$ & $\mathrm{PhCH}\left(\mathrm{CH}_{3}\right) \mathrm{Cl}$ \\
\hline 4 & $\begin{array}{l}\mathrm{PhCH}\left(\mathrm{CH}_{3}\right) \mathrm{CN} \\
\text { (standard) }\end{array}$ & $132(4)$ & $131(38)$ & $130(4)$ & $117(10)$ & $116(100)$ & $115(-)$ & $c$ & $\mathrm{PhCH}\left(\mathrm{CH}_{3}\right) \mathrm{Cl}$ \\
\hline 5 & $\mathrm{PhCH}\left(\mathrm{CH}_{3}\right)^{13} \mathrm{CN}$ & $133(1)$ & $132(10)$ & $131(33)$ & $118(2)$ & $117(30)$ & $116(100)$ & $\left({ }^{13} \mathrm{C}, 15\right)^{b}$ & $\mathrm{Ph}\left(=\mathrm{NCH}_{2} \mathrm{CN}\right) \mathrm{CH}_{3}$ \\
\hline \multicolumn{10}{|c|}{$\begin{array}{l}{ }^{a} \text { Entries 1,2: products of the reactions of the imines } * 1 \mathrm{c} \text { and } 1 \mathrm{c}^{*} \text { carried out in refluxing DMF solutions in the presence of } \mathrm{K}_{2} \mathrm{CO} \text {, according to } \\
\text { conditions of eqn. (1). Entries 3,4: products synthesised from } \mathrm{PhCH}\left(\mathrm{CH}_{3}\right) \mathrm{Cl} \text { and } \mathrm{Na}^{13} \mathrm{CN}\left({ }^{13} \mathrm{C}, 99 \% \text {; entry } 3\right) \text { or NaCN }(\mathrm{entry} 4) \text {. Entry } 5 \text { : product } \\
\text { obtained from the reaction of } \mathrm{Ph}\left(=\mathrm{NCH}_{2} \mathrm{CN}\right) \mathrm{CH}_{3} \text { in the presence of an equimolar amount of } \mathrm{Na}^{13} \mathrm{CN}\left({ }^{13} \mathrm{C}, 99 \%\right) \text {, under the conditions of eqn. }(1) \text {. } \\
{ }^{b} \text { Evaluated from mass spectra of labelled and unlabelled 2-phenylpropionitrile standards }\left[\mathrm{PhCH}\left(\mathrm{CH}_{3}\right)^{13} \mathrm{CN} \text { and } \mathrm{PhCH}\left(\mathrm{CH} \mathrm{CH}_{3}\right) \mathrm{CN}\right] \text { reported in entries } \\
3 \text { and 4, respectively. }{ }^{c} \text { Natural abundance of }{ }^{13} \mathrm{C} \text {. }\end{array}$} \\
\hline
\end{tabular}

proceed. Moreover, the $\mathrm{CN}^{-}$molar amount released by the reaction $\mathbf{1} \rightarrow \mathbf{2}$ was shown to be equal to the molar yield of products 2: that is, the overall rearrangement proceeds via the loss of $\mathrm{HCN}$.

These facts lead us to believe that cyanide may act as a leaving group along the reaction pathway. If this is the case, the cyano functionality of nitriles $\mathbf{2}$ may perhaps derive from the iminomethylene fragment $\left(=\mathbf{N C H}_{2}-\mathrm{CN}\right)$ of the reacting imines 1.

In this sense, further evidence is provided by the fact that $C$-alkylated imines $\mathbf{5 a}, \mathbf{b}$ do not rearrange to the respective nitriles, suggesting that the $=\mathrm{NCH}_{2}-$ is likely incorporated in nitriles 2 through an intramolecular mechanism.

To study these aspects in detail, labelled imines $\mathrm{PhC}$ $\left(=\mathrm{NCH}_{2}{ }^{13} \mathrm{CN}\right) \mathrm{CH}_{3}\left({ }^{*} \mathbf{1 c}\right)$ and $\mathrm{PhC}\left(={ }^{15} \mathrm{NCH}_{2} \mathrm{CN}\right) \mathrm{CH}_{3}\left(1 \mathrm{c}^{*}\right)$ were prepared and reacted under the usual conditions. The outcome of the reaction was monitored by GC/MS.

From the data in Table 2, isotopic enrichments of 32 and 57\% can be calculated for the two obtained products $* \mathbf{2} \mathbf{c}[\mathrm{PhCH}-$ $\left.\left(\mathrm{CH}_{3}\right)^{13} \mathrm{CN}\right]$ and $2 \mathrm{c}^{*}\left[\mathrm{PhCH}\left(\mathrm{CH}_{3}\right) \mathrm{C}^{15} \mathrm{~N}\right]$, respectively (entries $1,2)$. These results indicate that the cyano functionality of nitriles 2 derives from both the cyano [CN, (A)] and the iminomethylene $\left[=\mathrm{NCH}_{2}-,(\mathbf{B})\right]$ fragments of the reagents. However, a definite regioselectivity is observed: the values of the isotopic enrichments for $* \mathbf{2 c}$ and $\mathbf{2} \mathbf{c} *$ (32 and $57 \%$, respectively) indicate that the cyano group originates mainly from the iminomethylene part (B) of the reagent, in a 2:1 ratio with respect to portion (A). Since it is hardly imaginable that fragment $\mathbf{B}$ can be lost from the substrate (and successively reintroduced in the product), this behaviour suggests that the reaction has to proceed mainly via an intramolecular process. However, the labelled minor product coming from A does not exclude an intermolecular reaction involving a labelled cyanide fragment previously eliminated from the substrate.

A crossover experiment was therefore carried out in order to elucidate whether the reaction proceeds through an intra- or an intermolecular process. In particular, the unlabelled imine 1c $\left[\mathrm{PhC}\left(=\mathrm{NCH}_{2} \mathrm{CN}\right) \mathrm{CH}_{3}\right]$ was reacted according to the conditions of eqn. (1) (refluxing DMF, 1.5 molar excess of $\mathrm{K}_{2} \mathrm{CO}_{3}$ ) in the presence of an equimolar amount of $\mathrm{Na}^{13} \mathrm{CN}\left({ }^{13} \mathrm{C}, 99 \%\right)$. Entry 5 of Table 2 reports the mass peak abundances of the obtained 2-phenylpropionitrile, which corresponds to a labelled isotopic enrichment of $15 \%$. Although the occurrence of the crossover reaction shows that an intermolecular process operates, the low isotopic enrichment $(15 \%)$ of the product also indicates that the intermolecular reaction occurs only to a low extent.

In order to explain formation of $* \mathbf{2} \mathbf{c}$, we propose that the ${ }^{13} \mathrm{CN}^{-}$generated from the reaction of $* 1 \mathrm{c}$ [eqn. (3)] can undergo exchange with the $-\mathrm{CN}$ of $\mathbf{2 c}$. This kind of isotopic crossover is documented for acetonitrile, which undergoes nitrile exchange with labelled cyanide. ${ }^{13}$

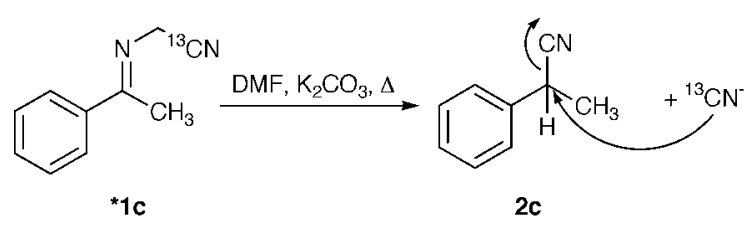

In our opinion, this exchange determines the degree of scrambling. The apparent contradiction of the lower enrichment observed by adding labelled cyanide to the reaction of $\mathbf{1 c}$ $\left({ }^{13} \mathrm{C}, 15 \%\right)$, compared with the reaction of $* 1 \mathbf{c}$ without added labelled cyanide [eqn. (3): ${ }^{13} \mathrm{C}, 32 \%$ ] might be accounted for by a solvent cage effect, which favours attack of ${ }^{13} \mathrm{CN}^{-}$on $2 \mathrm{c}$ with respect to its diffusion [eqn. (3)]. Thus, exchange becomes preferred with respect to the case where ${ }^{13} \mathrm{CN}^{-}$is added to the reaction mixture.

\section{Mechanistic pattern}

The conclusions drawn from (i) the Hammett equation applied to $p$-phenyl substituted imines $\mathbf{1}$, (ii) the study of the reactivity of $N$-alkylformimidoyl cyanides $\mathbf{4}$, and (iii) the reaction of imines 1 with $n$-BuLi and their subsequent alkylation, strongly suggest that the initial rate-determining step of the mechanism is deprotonation at the methylene carbon to yield $\mathbf{1}^{-}$, while a double bond isomerisation can be excluded.

In addition, the reaction is dramatically sensitive to the structure of imines $\mathbf{1}$. Under the same reaction conditions, similar compounds such as $\mathrm{PhC}\left(=\mathrm{NCH}_{2} \mathrm{Ph}\right) \mathrm{CH}_{3}$ do not give either $\mathrm{PhCH}(\mathrm{R}) \mathrm{CN}$ or $\mathrm{PhCH}\left(\mathrm{CH}_{3}\right) \mathrm{Ph}$. This observation, together with the recovery of cyanide from the reaction mixture, strengthens the hypothesis that the cyano group of imines $\mathbf{1}$ behaves as a leaving group which is not found later in the product nitrile, unless by a $\mathrm{CN}$ exchange on the final nitrile 2 .

The tests carried out on isotopically labelled imines 1 suggest that the reaction proceeds through a mechanism mainly based upon an intramolecular process: in particular, the iminomethylene fragment $\left(=\mathrm{NCH}_{2}-\right)$ of the reagent is the primary source of cyano groups into the product 2 .

In our view, these combined observations justify a general mechanistic hypothesis, which involves an intramolecular nucleophilic attack by the carbanion $\mathbf{1}^{-}$on the imine carbon to form an azirine ring system (Scheme 4).

The analogous spiro( $2 H$-azirine- $2,9^{\prime}$-fluorene) intermediate was previously isolated in the reaction of 9-(azidomethylene)fluorene, and further reacted to yield a mixture of 9-cyano- and 9-isocyanofluorene. ${ }^{14}$

The formation of the aziridine $\mathbf{6}$ is the common starting point for the two following different pathways.

Route "a". The aziridine 6 deprotonates on the nitrogen, to 


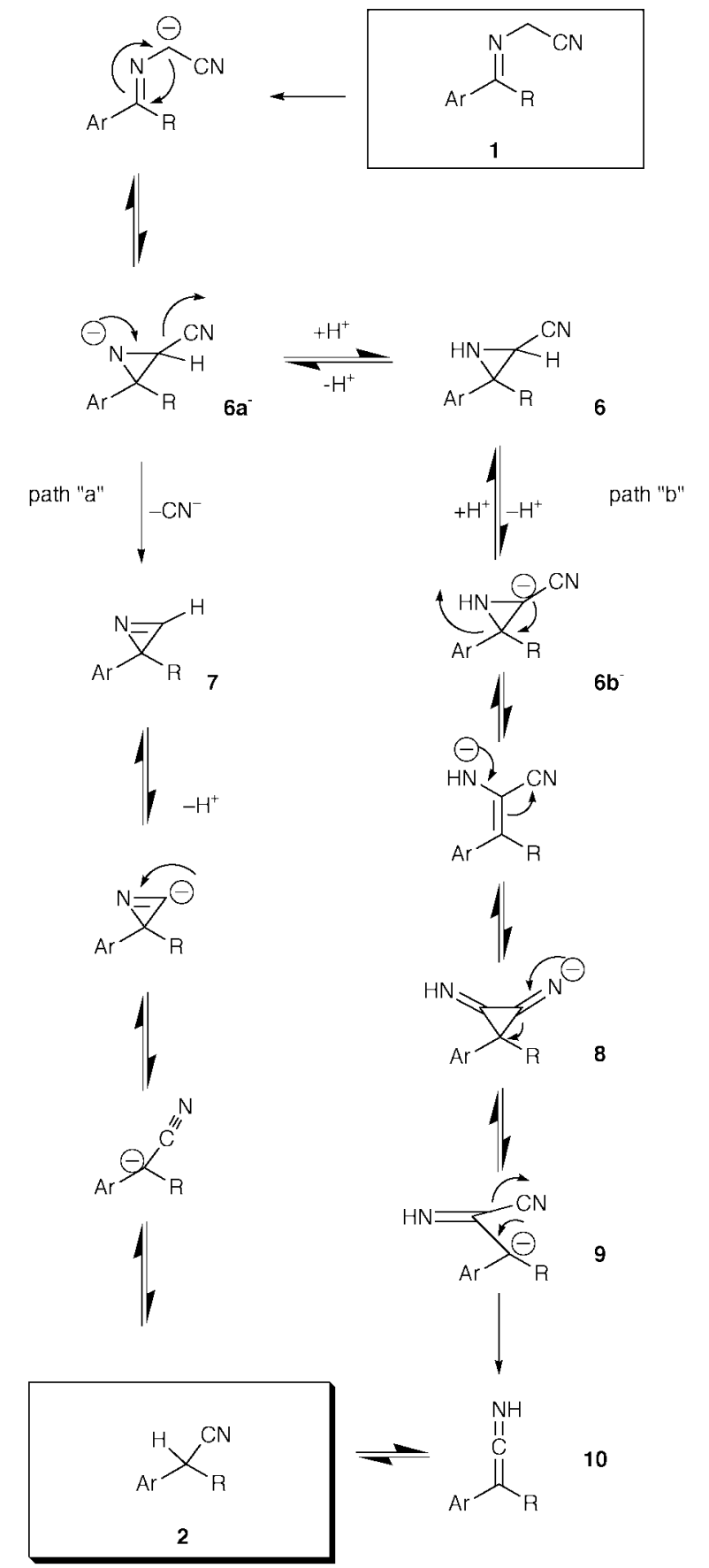

Scheme 4 Hypotheses for the mechanisms of the base catalysed rearrangement of imines $\mathbf{1}$ to nitriles $\mathbf{2}$.

yield anion $6 \mathrm{a}^{-}$, which expels cyanide to form the azirine 7 (the $\mathrm{CN}$ group here behaves somewhat like in the benzoin condensation: it favours deprotonation of $\mathbf{6}$ and then acts as a leaving group), which isomerises by protonation-reprotonation and yields nitrile 2 . This pathway requires that $100 \%$ of the final CN derives from the iminomethylene fragment of the starting imine. The observed label scrambling must therefore take place in a second step, as proposed earlier [eqn. (3)].

In addition, $2 H$-azirines have been proposed as intermediates also in the conversion of vinyl azides to nitriles. ${ }^{14}$

Route "b". The aziridine $\mathbf{6}$ deprotonates on the carbon, to yield anion $\mathbf{6} \mathbf{b}^{-}$, which by successive rearrangements forms the intermediate $\mathbf{8}$. This intermediate offers, by prototropy, a pathway for both the cyano and iminomethylene functions to contribute to the retained and expelled cyano groups in the product. Finally, intermediate 9 may expel $\mathrm{CN}^{-}$and provide $\mathbf{1 0}$, which rearranges to the product 2 . The major drawback of this second route lies in the degree of symmetry of intermediate $\mathbf{8}$ : this would provide a complete scrambling of the isotopes, and therefore does not account for the iminomethylene fragment as the preferential source of the cyano group, according to the isotope labelling studies.

The two suggested pathways for the rearrangement also rationalise the fact that alkylated imines $\mathbf{5 a}$ and $\mathbf{5 b}$ do not undergo the rearrangement. Neither the intermediate aziridine 6 nor the azirine of route "a", nor the intermediate $\mathbf{6 b}^{-}$of route " $b$ " would be able to rearrange to the nitrile because of the missing proton on the heterocycle.

At this stage it is not possible to choose one mechanism $v s$. another, though our preference goes to path "a" of Scheme 4, which better justifies the observed degree of isotopic scrambling. Additional work is therefore in progress, aimed at the synthesis and study of the reactivity of the postulated azirine and aziridine intermediates.

The moderate yields $(40-65 \%)$ of nitriles 2, which are reported in Table 1, may perhaps be explained based on the previous considerations. An initial anionic species, such as the proposed one, may undergo intermolecular reactions, leading to the formation of uncharacterisable tars, which are observed as by-products of our reaction (except for minor amounts, $\leq 5 \%$, of the corresponding ketones, ArCOR). Also $N$-alkyliminoacetonitriles $(\mathrm{R}-\mathrm{N}=\mathrm{CHCN})$ have been claimed to form oligomers by an anionic mechanism under mildly alkaline conditions at room temperature. ${ }^{15}$

Therefore, the starting $\mathrm{CN}$ content present in reagent $\mathbf{1}$ is distributed in two portions: it either ends up as cyanide when the intramolecular rearrangement occurs and $\mathbf{2}$ is formed (as observed by titration) or it may form organic polymers via an intermolecular process.

\section{Conclusions}

The reported experimental evidence sketches out a working hypothesis toward the final determination of the reaction pathway, through the mechanism of Scheme 4. Future work will fill in the reaction steps by independently synthesising some of the proposed intermediates, and subjecting them to the reaction conditions of Scheme 1.

The significance of the studied transformation lies in its synthetic applicability, and in its mechanistic relevance. More importantly, the reaction is unprecedented, and it opens an unexplored area of investigation which hopefully will allow expansion of its scope, by using functional groups other than CN.

\section{Experimental}

\section{General}

All compounds were ACS grade and used without further purification. Melting points are uncorrected. ${ }^{1} \mathrm{H}$ NMR spectra were recorded at $400 \mathrm{MHz}$ on a Varian Unity Spectrometer, using $\mathrm{CDCl}_{3}$ as solvent and TMS as the internal standard. GC analyses were performed using a $30 \mathrm{~m}$ DB5 capillary column. GCMS analyses were carried out using an HP mass detector at $70 \mathrm{eV}$ coupled to a gas chromatograph fitted with a $30 \mathrm{~m}$ DB5 capillary column. The fitting curves of experimental data were obtained using the Microcal Origin software.

Preparation of $\mathrm{N}$-(1-arylethylidene)cyanomethyl amines (1a-e) and labelled $N$-(1-phenylethylidene)cyanomethyl amines $\left({ }^{*} 1 \mathrm{c}\right.$, 1c*)

$N$-(1-Arylethylidene)cyanomethyl amines 1a-e were prepared by the condensation of the corresponding ketones $\left(p-\mathrm{XC}_{6} \mathrm{H}_{4}-\right.$ $\mathrm{COCH}_{3} ; \mathrm{X}=\mathrm{Br}, \mathrm{Cl}, \mathrm{H}, \mathrm{CH}_{3} \mathrm{O}$ and $\mathrm{CH}_{3}$, respectively) with $\mathrm{NH}_{2} \mathrm{CH}_{2} \mathrm{CN} \cdot \mathrm{HCl}$ according to a procedure previously reported by us. ${ }^{4}$ Likewise, labelled $N$-(1-phenylethylidene)cyanomethyl 
amines [ ${ }^{*} 1 \mathrm{c}: \mathrm{PhC}\left(=\mathrm{NCH}_{2}{ }^{13} \mathrm{CN}\right) \mathrm{CH}_{3} ; 1 \mathbf{c}^{*}: \mathrm{PhC}\left(={ }^{15} \mathrm{NCH}_{2} \mathrm{CN}\right)$ $\mathrm{CH}_{3}$ ] were prepared using $\mathrm{NH}_{2} \mathrm{CH}_{2}{ }^{13} \mathrm{CN} \cdot \mathrm{H}_{2} \mathrm{SO}_{4}\left({ }^{13} \mathrm{C}, 99 \%\right)$ and ${ }^{15} \mathrm{NH}_{2} \mathrm{CH}_{2} \mathrm{CN} \cdot \mathrm{H}_{2} \mathrm{SO}_{4}\left({ }^{15} \mathrm{~N}, 99 \%\right)$, respectively, as the iminating agents of acetophenone. In turn, the labelled aminoacetonitrile salts were synthesised by using ${ }^{13} \mathrm{NaCN}\left({ }^{13} \mathrm{C}, 99 \%\right)$ or ${ }^{15} \mathrm{NH}_{4} \mathrm{Cl}$ $\left({ }^{15} \mathrm{~N}, 99 \%\right)$, according to reported procedures. ${ }^{16}$ Both the imines *1c and $1 \mathbf{c}^{*}$ were not isolated; they were directly reacted to yield the corresponding nitriles $* \mathbf{2} \mathbf{c}$ and $\mathbf{2} \mathbf{c}^{*}$, respectively.

$N$-[1-(p-Bromophenyl)ethylidene]cyanomethyl amine 1a.

Starting from $6.0 \mathrm{~g}$ of $p$-bromoacetophenone, $3.7 \mathrm{~g}$ of $\mathbf{1 a}$ was obtained $(96 \%$ pure by $\mathrm{GC} ; 52 \%$ yield $) ; \mathrm{mp} 96-98{ }^{\circ} \mathrm{C}$. The product was recrystallised from $n$-pentane-diethyl ether $(95: 5$ v/v). ${ }^{1} \mathrm{H} \mathrm{NMR}\left(\mathrm{CDCl}_{3}\right) \delta: 2.29\left(\mathrm{~s}, 3 \mathrm{H}, \mathrm{CH}_{3}\right), 4.38\left(\mathrm{~s}, 2 \mathrm{H}, \mathrm{CH}_{2}\right)$, 7.54 (dd, 2H, Ar; $\left.J 8.8 \mathrm{~Hz}, J^{\prime} 2.0 \mathrm{~Hz}\right), 7.70$ (dd, 2H, Ar; $J 8.8$ $\mathrm{Hz}, J^{\prime} 2.0 \mathrm{~Hz}$ ). Mass spectrum $(70 \mathrm{eV}) \mathrm{m} / \mathrm{z}$ (relative intensity): 238 (29), 237 (M+, 40), 236 (29), 235 (39), 223 (96), 221 (100), 183 (55), 181 (54), 157 (18), 102 (41), 75 (22), 76 (17).

$N$-[1-(p-Chlorophenyl)ethylidene]cyanomethyl amine $\mathbf{1 b}$. Starting from $5.0 \mathrm{~g}$ of $p$-chloroacetophenone, $4.4 \mathrm{~g}$ of $\mathbf{1 b}$ was obtained $\left(99 \%\right.$ pure by GC; $71 \%$ yield); $\mathrm{mp} 60-64{ }^{\circ} \mathrm{C}$. The product was recrystallised from $n$-pentane-diethyl ether $(95: 5$ v/v). ${ }^{1} \mathrm{H}$ NMR $\left(\mathrm{CDCl}_{3}\right) \delta: 2.29\left(\mathrm{~s}, 3 \mathrm{H}, \mathrm{CH}_{3}\right), 4.38\left(\mathrm{~s}, 2 \mathrm{H}, \mathrm{CH}_{2}\right)$, $7.38(\mathrm{~d}, 2 \mathrm{H}, \mathrm{Ar} ; J 8.8 \mathrm{~Hz}), 7.77$ (d, 2H, Ar; $J 8.8 \mathrm{~Hz})$. Mass spectrum $(70 \mathrm{eV}) \mathrm{m} / \mathrm{z}$ (relative intensity): 194 (9), $193(15), 192$ $\left(\mathrm{M}^{+}, 28\right), 191$ (38), $180(4), 179$ (34), 178 (11), 177 (100), 152 (8), 150 (11), 139 (18), 137 (55), 102 (12), 75 (12).

$\mathrm{N}$-(1-Phenylethylidene)cyanomethyl amine 1c. Full data are in ref. 4.

$N$-[1-(p-Methoxyphenyl)ethylidene]cyanomethyl amine 1d. Starting from $5.0 \mathrm{~g}$ of $p$-methoxyacetophenone, $5.0 \mathrm{~g}$ of $1 \mathrm{~d}$ was obtained ( $98 \%$ pure by $\mathrm{GC} ; 80 \%$ yield); $\mathrm{mp} 46-47.5^{\circ} \mathrm{C}$. The product was recrystallised from $n$-hexane- $\mathrm{CHCl}_{3}(95: 5 \mathrm{v} / \mathrm{v})$. ${ }^{1} \mathrm{H} \mathrm{NMR}\left(\mathrm{CDCl}_{3}\right) \delta: 2.29\left(\mathrm{~s}, 3 \mathrm{H}, \mathrm{CH}_{3}\right), 3.85\left(\mathrm{~s}, 3 \mathrm{H}, \mathrm{OCH}_{3}\right), 4.38$ (s, 2H, $\left.\mathrm{CH}_{2}\right), 6.91$ (dd, 2H, Ar; J 9.2, J' $2.0 \mathrm{~Hz}$ ), 7.8 (dd, 2H, Ar; $J 9.2, J^{\prime} 2.0 \mathrm{~Hz}$ ). Mass spectrum $(70 \mathrm{eV}) \mathrm{m} / \mathrm{z}$ (relative intensity): 189 (6), $188\left(\mathrm{M}^{+}, 50\right), 187$ (31), 174 (8), 173 (68), 134 (10), 133 (100), 103 (8), 90 (8), 80 (9), 77 (7), 55 (8).

$N$-[1-(p-Methylphenyl)ethylidene]cyanomethyl amine $1 \mathrm{e}$. Starting from $5.0 \mathrm{~g}$ of $p$-methylacetophenone, $3.5 \mathrm{~g}$ of $1 \mathrm{e}$ was obtained ( $98 \%$ pure by GC; $55 \%$ yield); mp $29-31{ }^{\circ} \mathrm{C}$. The product was recrystallised from $n$-hexane. ${ }^{1} \mathrm{H}$ NMR $\left(\mathrm{CDCl}_{3}\right)$ $\delta: 2.29\left(\mathrm{~s}, 3 \mathrm{H}, \mathrm{CH}_{3}\right), 2.38\left(\mathrm{~s}, 3 \mathrm{H}, \mathrm{CH}_{3}\right), 4.38\left(\mathrm{~s}, 2 \mathrm{H}, \mathrm{CH}_{2}\right), 7.47$ (d, 2H, Ar), 7.71 (d, 2H, Ar). Mass spectrum $(70 \mathrm{eV}) \mathrm{m} / \mathrm{z}$ (relative intensity): $172\left(\mathrm{M}^{+}, 17\right), 171(20), 158(11), 157$ (100), 130 (16), 117 (58), 116 (24), 91 (12), 89 (12), 77 (6), 65 (12). The product decomposes on standing.

${ }^{13} \mathrm{C}$-labelled $\mathrm{N}$-(1-phenylethylidene)cyanomethyl amine *1c, $\mathbf{P h C}\left(=\mathrm{NCH}_{2}{ }^{13} \mathbf{C N}\right) \mathbf{C H}_{3}$. Under the conditions reported in ref. 4, acetophenone $(0.25 \mathrm{~g})$ was reacted with $\mathrm{NH}_{2} \mathrm{CH}_{2}{ }^{13} \mathrm{CN} \cdot \mathrm{H}_{2} \mathrm{SO}_{4}$ $\left({ }^{13} \mathrm{C}, 99 \%\right.$; $0.51 \mathrm{~g}$ ), affording ${ }^{*} 1 \mathrm{c}$ in $88 \%$ yield (by GC). The product $* 1 \mathbf{c}$ was not isolated. The structure was confirmed by GC/MS. Mass spectrum $(70 \mathrm{eV}) \mathrm{m} / \mathrm{z}$ (relative intensity): 159 $\left(\mathrm{M}^{+}, 17\right), 158$ (43), 145 (9), 144 (100), 117 (8), 116 (22), 103 (31), 82 (8), 77 (16), 76 (8), 51 (12).

${ }^{15} \mathrm{~N}$-labelled $\mathrm{N}$-(1-phenylethylidene)cyanomethyl amine $1 \mathrm{c}^{*}$, $\mathrm{PhC}\left(={ }^{15} \mathrm{NCH}_{2} \mathrm{CN}\right) \mathbf{C H}_{3}$. Under the conditions reported in ref. 4, acetophenone $(0.25 \mathrm{~g})$ was reacted with ${ }^{15} \mathrm{NH}_{2} \mathrm{CH}_{2} \mathrm{CN} \cdot \mathrm{H}_{2} \mathrm{SO}_{4}$ $\left({ }^{15} \mathrm{~N}, 99 \%\right.$; $0.51 \mathrm{~g}$ ), affording $1 \mathrm{c}^{*}$ in $83 \%$ yield (by GC). The product $1 \mathbf{c}^{*}$ was not isolated. The structure was confirmed by GC/MS. Mass spectrum $(70 \mathrm{eV}) \mathrm{m} / \mathrm{z}$ (relative intensity): 159 $\left(\mathrm{M}^{+}, 22\right), 158$ (52), 145 (10), 144 (100), 118 (6), 117 (23), 104 (31), 82 (9), 77 (13), 51 (9). The peaks 117 and 104 of compound $1 c^{*}$ represent the $\left(\mathrm{PhC}={ }^{15} \mathrm{NCH}\right)^{+}$and $\left(\mathrm{PhC}={ }^{15} \mathrm{~N}\right)^{+}$frag- ments; they confirm the position of labelled isotope ${ }^{15} \mathrm{~N}$. In fact, for both compounds $1 \mathrm{c}$ and $* \mathbf{1 c}$, the same fragments appear shifted by one mass unit at $m / z 116$ and 103 , respectively.

Preparation of $\mathrm{N}$-[1-(ethyl)ethylidene]cyanomethyl amine $1 \mathrm{~g}$. According to the above reported procedure, ${ }^{4}$ the dialkyl imine $1 \mathrm{~g}(1.15 \mathrm{~g}, 10.5 \mathrm{mmol} ; 75 \%)$ was obtained as a dense yellow liquid by condensing methyl ethyl ketone $(1.0 \mathrm{~g}, 13.9 \mathrm{mmol})$ with $\mathrm{NH}_{2} \mathrm{CH}_{2} \mathrm{CN} \cdot \mathrm{HCl} .{ }^{1} \mathrm{H} \mathrm{NMR}\left(\mathrm{CDCl}_{3}\right) \delta: 1.09\left(\mathrm{t}, 3 \mathrm{H}, \mathrm{CH}_{3}\right.$, $J 7.32$ ), 1.90 (s, $3 \mathrm{H}, \mathrm{CH}_{3}$ ), 2.33 (q, $\left.2 \mathrm{H}, \mathrm{CH}_{2}, J 7.32\right), 4.15$ (s, $1 \mathrm{H}$, $\mathrm{CH}_{2} \mathrm{CN}$ ). Mass spectrum $(70 \mathrm{eV}) \mathrm{m} / \mathrm{z}$ (relative intensity): 11 $\left(\mathrm{M}^{+}, 110\right), 95$ (14), 81 (100), 70 (14), 68 (22), 67 (11), 54 (60). The product turned to a brown colour on standing.

General procedure for the transformation of imines 1a-e into the corresponding nitriles $2 \mathrm{a}-\mathrm{e}$

A DMF $(10 \mathrm{~mL})$ solution of the substrate $(0.13 \mathrm{M} ; 10 \mathrm{~mL})$ containing the internal standard (0.3 molar with respect to $\mathbf{1}$; $n$-tetradecane for $\mathbf{1 a , c , d}, n$-hexadecane for $\mathbf{1 b}$, and $n$-dodecane for 1e, respectively) and $\mathrm{K}_{2} \mathrm{CO}_{3}$ (in 1.5 molar excess with respect to the reactant 1) was loaded in a three-necked, roundbottomed flask fitted with a silicone septum for sampling, a refluxing condenser capped with a stopcock, and another stopcock. The mixture was degassed by vacuum/ $\mathrm{N}_{2}$ cycles and nitrogen was admitted from a rubber reservoir and maintained throughout the reaction. Then, the mixture was heated under stirring at the reflux temperature $\left(153^{\circ} \mathrm{C}\right)$; after a few minutes the solution becomes a characteristic dark brown-red colour. The reaction course was followed by GC. ATTENTION! The reaction mixture contains cyanide, great care must be used for all further operations.

Under the same conditions, the imine $1 \mathrm{c}\left[\mathrm{PhC}\left(=\mathrm{NCH}_{2} \mathrm{CN}\right)-\right.$ $\mathrm{CH}_{3}$ ] was also reacted in the presence of an equimolar amount of $\mathrm{Na}^{13} \mathrm{CN}\left({ }^{13} \mathrm{C}, 99 \%\right)$.

Compounds $2 \mathbf{a}-\mathbf{e}$ were not isolated: their characterisation was through GC/MS analysis by comparison with authentic samples. ${ }^{2 c, 3}$

The reactions of labelled imines *1c and $1 \mathrm{c} *$. As above described, solutions of the crude imines $* 1 \mathbf{c}$ and $1 \mathbf{c}^{*}$ in DMF were obtained by condensing acetophenone with $\mathrm{NH}_{2} \mathrm{CH}_{2}-$ ${ }^{13} \mathrm{CN} \cdot \mathrm{H}_{2} \mathrm{SO}_{4}\left({ }^{13} \mathrm{C}, 99 \%\right)$ and ${ }^{15} \mathrm{NH}_{2} \mathrm{CH}_{2} \mathrm{CN} \cdot \mathrm{H}_{2} \mathrm{SO}_{4}\left({ }^{15} \mathrm{~N}, 99 \%\right)$, respectively. According to the same procedure used for compounds $1 \mathbf{a}-\mathbf{e}$, the solutions of $* \mathbf{1} \mathbf{c}$ and $1 \mathbf{c}^{*}$ were then added to $\mathrm{K}_{2} \mathrm{CO}_{3}$ (1.5 molar excess with respect to the reacting imine), and heated under stirring at the reflux temperature.

The labelled 2-phenylpropionitriles $\left({ }^{*} \mathbf{2 c}\right.$ and $\left.\mathbf{2} \mathrm{c}^{*}\right)$ were not isolated and they were characterized by GC/MS as described in Table 2

\section{Preparation of $\mathrm{N}$-alkylformimidoyl cyanides $(4 \mathrm{c}, \mathrm{f}, \mathrm{g})$}

$N$-Alkylformimidoyl cyanides $\mathbf{4 c , f , g}$ were prepared by a new method ${ }^{20}$ devised as a modification of reported $N$-chlorination and dehydrochlorination procedures. ${ }^{8}$ Accordingly, the appropriate amines $\mathrm{RR}^{\prime} \mathrm{CHNHCH}{ }_{2} \mathrm{CN}\left(\mathrm{R}=\mathrm{Ph}, \mathrm{R}^{\prime}=\mathrm{CH}_{3} ; \mathrm{R}=\mathrm{Et}\right.$, $\left.\mathrm{R}^{\prime}=\mathrm{CH}_{3}\right)^{8,17}$ were added dropwise to a vigorously stirred aqueous solution of $\mathrm{NaOCl}(1.5 \mathrm{M} ; 10-13 \%$ available chlorine; 1.2 molar equiv. with respect to the amine), providing that the reaction temperature was kept below $10{ }^{\circ} \mathrm{C}$. Then, the mixture was allowed to warm to room temperature, stirred for $1 \mathrm{~h}$, and extracted with diethyl ether $(3 \times 25 \mathrm{~mL})$. The combined organic layers were dried over $\mathrm{Na}_{2} \mathrm{SO}_{4}$, and, after filtration, the diethyl ether was carefully removed by rotary evaporation. Compound $\mathbf{4 g}$ was further purified by distillation.

In the case of the solid amine $\mathrm{Ph}_{2} \mathrm{CHNHCH}_{2} \mathrm{CN}(0.5 \mathrm{~g})$, the reaction was run dissolving the amine in dioxane $(4 \mathrm{~mL})$. When used neat, no reaction took place at all.

$\mathrm{N}$-sec-Butylformimidoyl cyanide 4g. Starting from $\mathrm{N}$-sec- 
butylaminoacetonitrile $(5.0 \mathrm{~g}, 44.6 \mathrm{mmol}),{ }^{17}$ a mixture of $\mathbf{4 g}$ and starting amine was obtained in a 95:5 ratio, respectively $\left(2.68 \mathrm{~g}\right.$; bp $\left.66-69^{\circ} \mathrm{C}, 20 \mathrm{mmHg}\right) .4 \mathrm{4g}, E$ isomer: ${ }^{1} \mathrm{H}$ NMR $\left(\mathrm{CDCl}_{3}\right) \delta: 0.81\left(\mathrm{t}, 3 \mathrm{H}, \mathrm{CH}_{3}, J 7.2 \mathrm{~Hz}\right), 1.22\left(\mathrm{~d}, 3 \mathrm{H}, \mathrm{CH}_{3}, J 7.2\right.$ $\mathrm{Hz}$ ), 1.60 (quintet, $2 \mathrm{H}, \mathrm{CH}_{2}, J 7.2 \mathrm{~Hz}$ ), $3.26(\mathrm{q}, 1 \mathrm{H}, \mathrm{CH}, J 7.2$ $\mathrm{Hz}), 7.35(\mathrm{~s}, 1 \mathrm{H}, \mathrm{N}=\mathrm{CH})$; traces $(\leq 5 \%)$ of the $Z$ isomer were also detected. Mass spectrum $(70 \mathrm{eV}) \mathrm{m} / \mathrm{z}$ (relative intensity): 95 $\left(\mathrm{M}^{+}-\mathrm{CH}_{3}, 18\right), 82$ (16), 81 (100), 68 (13), 57 (22), 54 (44). The product rapidly decomposed on standing.

$\boldsymbol{N}$-( $\alpha$-Methyl)benzylformimidoyl cyanide $4 c$. Starting from $N$-( $\alpha$-methyl)benzylaminoacetonitrile $(1.0 \mathrm{~g}, 6.3 \mathrm{mmol}),{ }^{18}$ a mixture of $\mathbf{4 c}$, starting amine and $\mathbf{1 c}$ was obtained in an $88: 10: 2$ ratio, respectively ( $0.65 \mathrm{~g}$; not distilled). $4 \mathbf{c}, E$ isomer: ${ }^{1} \mathrm{H}$ NMR $\left(\mathrm{CDCl}_{3}\right) \delta: 1.59\left(\mathrm{~d}, 3 \mathrm{H}, \mathrm{CH}_{3}, J 6.6 \mathrm{~Hz}\right), 4.59(\mathrm{q}, 1 \mathrm{H}, \mathrm{CH}, J 6.6$ $\mathrm{Hz}$ ), 7.29-7.39 (m, Ph and $\mathrm{N}=\mathrm{CH})$; traces of the $Z$ isomer were also detected. Mass spectrum $(70 \mathrm{eV}) \mathrm{m} / \mathrm{z}$ (relative intensity): 158 ( $\left.\mathrm{M}^{+}, 6\right), 116$ (20), 106 (10), 105 (100), 103 (12), 79 (12), 77 (21), 51 (9). The initially pale yellow liquid turned to brown in $24 \mathrm{~h}$, even when stored at $+4{ }^{\circ} \mathrm{C}$.

The reaction of $\mathrm{Ph}_{2} \mathrm{CHNHCH}_{2} \mathrm{CN}$ gave a mixture of $\mathbf{1 f}$ $(60 \%)$, 4f $(25 \%)$ and $N$-( $\alpha$-methyl)benzylaminoacetonitrile $(15 \%)$. Products were not separated. 4f: mass spectrum $(70 \mathrm{eV})$ $\mathrm{m} / \mathrm{z}$ (relative intensity): $220\left(\mathrm{M}^{+}, 7\right), 168(15), 167(100), 166$ (12), 165 (34), 152 (19), 116 (8), 89 (7), 77 (7), 51 (5).

\section{Spectroscopic data of the secondary amines}

$N$-sec-Butylaminoacetonitrile. ${ }^{17}$ Starting from 10 g (137 mmol) of sec-butylamine, $9.95 \mathrm{~g}$ was obtained $\left(65 \%\right.$; bp $38^{\circ} \mathrm{C}$, $0.3 \mathrm{mmHg} ; 95 \%$ pure by GC). ${ }^{1} \mathrm{H}$ NMR $\left(\mathrm{CDCl}_{3}\right) \delta: 0.91(\mathrm{t}, 3 \mathrm{H}$, $\left.\mathrm{CH}_{3}, J 7.2 \mathrm{~Hz}\right), 1.05\left(\mathrm{~d}, 3 \mathrm{H}, \mathrm{CH}_{3}, J 6.6 \mathrm{~Hz}\right), 1.28$ (br s, $1 \mathrm{H}$, $\mathrm{NH}), 1.35\left(\mathrm{dq}, 1 \mathrm{H}, \mathrm{CH}_{2}, J 7.2 \mathrm{~Hz}\right), 1.47\left(\mathrm{dq}, 1 \mathrm{H}, \mathrm{CH}_{2}, J 7.2\right.$ $\mathrm{Hz}), 2.81$ (sextet, $1 \mathrm{H}, \mathrm{CH}, J 6.6 \mathrm{~Hz}), 3.66\left(\mathrm{dd}, 2 \mathrm{H}, \mathrm{CH}_{2} \mathrm{CN}\right.$, $J 8.2 \mathrm{~Hz}$ ); mass spectrum $(70 \mathrm{eV}) \mathrm{m} / \mathrm{z}$ (relative intensity): 158 $\left(\mathrm{M}^{+}, 6\right), 116(20), 106$ (10), 105 (100), 103 (12), 79 (12), 77 (21), 51 (9); IR $\left(\mathrm{CCl}_{4}\right): v / \mathrm{cm}^{-1} 2243(\mathrm{CN}), 3357(\mathrm{NH})$.

$N$-(a-Methyl)benzylaminoacetonitrile. ${ }^{18}$ Starting from $5 \mathrm{~g}$ (41.3 mmol) of ( $\alpha$-methyl)benzylamine, $2.5 \mathrm{~g}$ was obtained (38\%; bp 86-88 $\left.{ }^{\circ} \mathrm{C}, 0.2 \mathrm{mmHg}\right) .{ }^{1} \mathrm{H}$ NMR $\left(\mathrm{CDCl}_{3}\right) \delta: 1.41(\mathrm{~d}$, $\left.3 \mathrm{H}, \mathrm{CH}_{3}, J 7.8 \mathrm{~Hz}\right), 2.4($ br s, $1 \mathrm{H}, \mathrm{NH}), 3.42\left(\mathrm{dd}, 2 \mathrm{H}, \mathrm{CH}_{2} \mathrm{CN}\right.$, $J 17 \mathrm{~Hz}), 4.09$ (q, 1H, CH, J 7.8 Hz), 7.28-7.38 (m, 5H, Ph); mass spectrum $(70 \mathrm{eV}) \mathrm{m} / \mathrm{z}$ (relative intensity): $158\left(\mathrm{M}^{+}, 6\right), 116$ (20), 106 (10), 105 (100), 103 (12), 79 (12), 77 (21), 51 (9); IR $\left(\mathrm{CCl}_{4}\right): v / \mathrm{cm}^{-1} 2235(\mathrm{CN}), 3334(\mathrm{NH})$.

$N$-Benzhydrylaminoacetonitrile. Starting from $3 \mathrm{~g}$ (16.4 mmol) of benzhydrylamine, $2.4 \mathrm{~g}$ was obtained $(65 \%$; mp 73 $\left.74.5^{\circ} \mathrm{C}\right)$. The product was crystallised from $n$-hexane-diethyl ether $(2: 1 \mathrm{v} / \mathrm{v}) .{ }^{1} \mathrm{H}$ NMR $\left(\mathrm{CDCl}_{3}\right) \delta: 2.00(\mathrm{br} \mathrm{s}, 1 \mathrm{H}, \mathrm{NH}), 3.58$ (s, 2H, $\left.\mathrm{CH}_{2} \mathrm{CN}\right), 5.10$ (s, $\left.1 \mathrm{H}, \mathrm{CH}\right), 7.25-7.55(\mathrm{~m}, 10 \mathrm{H}, 2 \mathrm{Ph})$; mass spectrum $(70 \mathrm{eV}) \mathrm{m} / \mathrm{z}$ (relative intensity): $222\left(\mathrm{M}^{+}, 19\right)$, 168 (12), 167 (70), 166 (13), 165 (39), 152 (21), 146 (11), 145 (100), 144 (19), 104 (39), 77 (17), 67 (24), 51 (11); IR (KBr): $v / \mathrm{cm}^{-1} 2243(\mathrm{CN}), 3342(\mathrm{NH})$.

\section{Titration of the cyanide released by the reaction $1 \rightarrow 2$}

The particular case of $\mathrm{Ph}_{2} \mathrm{C}=\mathrm{NCH}_{2} \mathrm{CN}$ 1f was considered. 1f $(0.30 \mathrm{~g}, 1.4 \mathrm{mmol})$ was reacted under the conditions of Scheme 1 , and once the reaction was completed, the DMF solvent (10 $\mathrm{mL}$ ) was distilled off under vacuum. To the solid brown residue was added ultrapure water $(40 \mathrm{~mL}$, produced by a Millipore Milli-Q-plus system). The mixture was then extracted with diethyl ether $(3 \times 20 \mathrm{~mL})$. The aqueous phase was titrated by aq. $\mathrm{AgNO}_{3}(0.01 \mathrm{M}$ volumetric standard $)$ using established procedures: ${ }^{19}$ the concentration of the resulting cyanide solution was $1.8 \times 10^{-2} \mathrm{M}\left(0.72 \mathrm{mmol}\right.$ of $\mathrm{CN}^{-}$in $\left.40 \mathrm{~mL}\right)$.

The combined organic layers were dried over $\mathrm{Na}_{2} \mathrm{SO}_{4}$ and filtered. After removal of the solvent by rotary evaporation, the product $\left(\mathrm{Ph}_{2} \mathrm{CHCN}, \mathbf{2 f}\right)$ was purified by column chromatography: $48 \%$ yield $(0.13 \mathrm{~g}, 0.65 \mathrm{mmol})$.

The molar ratio $\mathrm{CN}^{-} / 2 \mathrm{f}$ was 1.1 .

\section{Reaction of 1 with $\boldsymbol{n}$-BuLi}

$\mathrm{Ph}_{2} \mathrm{C}=\mathrm{NCH}_{2} \mathrm{CN}$ if $(0.50 \mathrm{~g}, 2.3 \mathrm{mmol})$ dissolved in $15 \mathrm{~mL}$ of anhydrous THF was treated with $0.95 \mathrm{~mL}$ of $n$-BuLi $(2.5 \mathrm{M}$ in hexanes; $2.4 \mathrm{mmol}$ ) at $-90^{\circ} \mathrm{C}$, under $\mathrm{N}_{2}$. The solution turned brown.

Procedure A. The solution was warmed slowly to room temperature, THF was distilled off under vacuum and replaced with an equal amount of anhydrous DMF, and brought to the reflux temperature. The reaction was followed by GC: $2 \mathbf{f}$ was the sole product, identified by GC/MS by comparison with a known sample.

Procedure B. The solution was warmed to room temperature and quenched with 1.0 equiv. of either $n$ - $\mathrm{BuBr}$ or MeI. The mixture was cooled to $0{ }^{\circ} \mathrm{C}$, treated with water, washed with half saturated brine $(3 \times 20 \mathrm{~mL})$, the organic layer was dried over $\mathrm{Na}_{2} \mathrm{SO}_{4}$, filtered and the solvent removed by rotary evaporation. The products $\mathbf{5 a}$ and $\mathbf{5 b}$ were obtained as yellow oils, and were characterised by GC-MS and ${ }^{1} \mathrm{H}$ NMR.

5a. Yield $=90 \% .{ }^{1} \mathrm{H}$ NMR $\left(\mathrm{CDCl}_{3}\right) \delta: 7.16-7.86(\mathrm{~m}, 10 \mathrm{H}$, aromatic), $4.22(\mathrm{t}, 1 \mathrm{H}, J 6.6 \mathrm{~Hz}, \mathrm{CH}), 2.08-1.76(\mathrm{~m}, 2 \mathrm{H}), 1.52-$ $1.20(\mathrm{~m}, 4 \mathrm{H}), 0.89(\mathrm{t}, 3 \mathrm{H}, J 7.5 \mathrm{~Hz})$; mass spectrum $(70 \mathrm{eV}) \mathrm{m} / \mathrm{z}$ (relative intensity): $276\left(\mathrm{M}^{+}, 34\right), 275$ (92), 233 (12), 222 (12), 220 (24), 219 (80), 209 (18), 208 (100), 194 (11), 165 (37), 117 (10), 116 (93), 104 (34), 103 (13), 89 (14), 77 (32).

5b. Yield $=92 \%$. Mass spectrum $(70 \mathrm{eV}) \mathrm{m} / \mathrm{z}$ (relative intensity): 234 (M+ $\left.\mathrm{M}^{+}, 62\right), 233$ (74), 219 (12), 207 (25), 180 (48), 166 (23), 165 (37), 157 (20), 156 (12), 116 (100), 104 (78), 103 (14), 77 (71).

\section{Acknowledgements}

The authors wish to thank a Referee for suggesting a plausible mechanism for the rearrangement discussed in this paper (route "b" of Scheme 4).

This work was supported by MURST (Ministero dell'Università e della Ricerca Scientifica e Tecnologica), and by INCA (Consorzio Interuniversitario "la Chimica per l'Ambiente").

\section{References}

1 R. C. Larock, in Comprehensive Organic Transformations: A Guide to Functional Group Preparations, VCH, Weinheim, 1989.

2 (a) A. Kleemann and J. Engel, in Pharmazeutische Wirkstoffe, Synthesen, Patente, Anwendeungen, George Thieme Verlag, Stuttgart, New York, 1987; (b) J. P. Rieu, A. Boucherle, H. Cousse and G. Mouzin, Tetrahedron, 1986, 42, 4095; (c) M. Selva, C. A. Marques and P. Tundo, J. Chem. Soc., Perkin Trans. 1, 1994, 1323.

3 M. Selva, A. Bomben and P. Tundo, Synth. Commun., 1999, 29, 1561.

4 M. Selva, C. A. Marques and P. Tundo, Synth. Commun., 1995, 25, 369.

5 (a) J. H. Boyer, J. Dunn and J. Kooi, J. Chem. Soc., Perkin Trans. 1, 1975, 1743; (b) J. P. Ferris, R. S. Narang, T. A. Newton and V. R. Rao, J. Org. Chem., 1979, 44, 1273.

6 G. Pannetier and P. Souchay, in Chemical Kinetics, Elsevier, Barking (UK), 1967.

7 C. K. Ingold and C. L. Wilson, J. Chem. Soc., 1933, 1493.

8 (a) J. H. Boyer and J. Kooi, J. Am. Chem. Soc., 1976, 98, 1099; (b) J. R. Lindsay Smith, L. C. McKeer and J. Taylor, Org. Synth., 1989, 67, 222.

9 Nissan Chemical Industries, Ltd., Jpn. Kokai Tokkyo Koho, JP 59 46,257 (15 Mar 1984); Chem. Abstr., 1984, 101, 90603e.

10 J. March, in Advanced Organic Chemistry, 3 rd edn., J. Wiley \& Sons, New York, 1985, p. 244. 
11 H. Maskill, in The Physical Basis of Organic Chemistry, Oxford University Press, Oxford, 1989.

12 K. Bowden, N. B. Chapman and J. Shorter, Can. J. Chem., 1964, 42 1979.

13 M. Jay, W. J. Layton and G. A. Digenis, Tetrahedron Lett., 1980, 21, 2621.

14 W. Bauer and K. Hafner, Angew. Chem., Int. Ed. Engl., 1969, 8, 772.

15 J. P. Ferris, D. B. Donner and W. Lotz, J. Am. Chem. Soc., 1972, 94, 6968.

16 (a) W. K. Anslow and H. King, J. Chem. Soc., 1929, 2465; (b) R. Adams and W. D. Langley, Org. Synth., 1941, Coll. Vol. I, 355.
17 J. Corse, J. T. Bryant and H. A. Shonle, J. Am. Chem. Soc., 1946, 68, 1905.

18 T. Okawara and K. Harada, J. Org. Chem., 1972, 37, 3286.

19 A. Vogel, in A Textbook of Quantitative Inorganic Analysis, 3rd edn., Longman, London, 1961, 272.

20 A. Perosa, M. Selva and P. Tundo, Tetrahedron Lett., 1999, in the press.

Paper $9 / 05563 \mathrm{~K}$ 